\title{
About the Whereabouts of Indefinites ${ }^{*}$
}

\author{
Werner Frey \\ Zentrum für Allgemeine Sprachwissenschaft, Berlin \\ frey@zas.gwz-berlin.de
}

\begin{abstract}
The paper characterizes three different domains in the German middle field which are relevant for the interpretation of an indefinite. It is argued that the so-called 'strong' reading of an indefinite is the basic one and that the 'weak' reading needs special licensing which is mirrored by certain syntactic requirements. Some popular claims about the relation between the position and the interpretation of indefinites as well as some claims about scrambling are discussed and rejected. From the findings also follows that the strong reading of an indefinite is independent of its information status.
\end{abstract}

\section{Introduction}

That the interpretation of an indefinite depends on its environment has received the attention of linguists for quite some time. This variability of indefinites is of great interest because many important issues arise: the design of the syntax-semantics mapping, the function of scrambling, the influence of information structure on syntax and semantics, and the influence of prosodic phrasing on the position and the meaning of indefinites.

In the following, I would like to discuss some of the claims found in the literature. I will confront them mainly with the behavior of bare plurals in the middle field of the German clause, the realm of scrambling. Although German belongs to the languages which have already been widely discussed with respect to the behavior of indefinites, there are still a lot of data which might further stimulate the discussion. I will try to account for some of them with a proposal of my own.

\section{Where strong indefinites can be situated}

Diesing (1992) considered examples like the following:

(1) a. weil ja doch Kinder auf der Straße spielen since PRT PRT children on the street play 'since children do play on the street'

b. weil Kinder ja doch auf der Straße spielen

According to Diesing, the subject of (1a) gets an existential interpretation, whereas the subject of (1b) is interpreted generically. Diesing adopted the DRT view of indefinites

I wish to thank Chris Wilder and an anonymous reviewer.

The paper will also be published in Theoretical Linguistics 27, edited by Klaus von Heusinger and Kerstin Schwabe. 
(Kamp 1981): Indefinites do not have quantificational force of their own; rather the variable introduced by an indefinite has to be bound by another element of the structure. Diesing took modal particles like $j a$ doch as indicators of the VP boundary. To capture the difference in meaning between examples like in (1), Diesing formulated her famous mapping hypothesis for the relation between syntax and semantics:

(2) a. Material situated in the VP will be mapped into the nuclear scope (i.e. into the domain of 'existential closure').

b. Material outside VP will be mapped into the restriction of a quantificational structure.

The mapping in (2) is supposed to apply on LF. However, according to Diesing, the Sstructure positions of indefinites in the German clausal middle field already correspond to their positions on LF. Therefore, with regard to the middle field, the mapping in (2) operates on S-structure. In (1a) the indefinite stays inside the VP. According to (2a), it is interpreted existentially. In (lb), on the other hand, given Diesing's assumptions, the bare plural is outside the VP. (2b) says that it has to be mapped into the restrictive clause of a quantificational structure. According to Diesing, such a quantificational structure may arise from an implicit generic operator. This is the case in (1b), and the indefinite gets a generic reading.

According to (2), every indefinite inside the VP gets an existential reading. The existential reading is often called 'weak reading'. All the other readings are called 'strong'. The generic reading of $(\mathrm{lb})$ is one of the strong readings. Other strong readings are exemplified in (3):
a. da zwei Linguisten ja doch etwas dagegen hatten since two linguists PRT PRT something against have 'since two of the linguists had something against it'
b. weil ein Artikel von Otto ja doch bald erscheinen wird because an article by O. PRT PRT soon appear will 'because an article by $\mathrm{O}$. will soon appear'

The indefinite in (3a) is understood partitively, i.e, the sentence talks about two linguists belonging to a contextually given set. The indefinite in (3b) has a specific reading, i.e. the speaker has a certain article by Otto in mind.

That Diesing considers each of the examples in (1) as unambiguous is crucial for her approach. However, this assumption is problematic. Although an example like (1b) has in fact only the generic reading, the sentence in (1a) is actually ambiguous (cf. e.g. Haider \& Rosengren 1998, Frey \& Pittner 1998). It has an existential and a generic reading. The same is true for the following examples:

(4) a. weil Otto ja doch Fußballübertragungen anschaut because O. PRT PRT soccer broadcasts watches

b weil hier wer Bücher über Wissenschaftler kauft because here someone books about scientists buys

c. weil Abgeordnete Ostförderprogramme ablehnten because deputies support programs for East Germany rejected 
The objects in (4) can have a generic or an existential reading. In these examples the two readings are differentiated by different intonations (cf. Büring 2001). The generic reading is forced by stressing the object and the predicate, the existential reading is the result of stressing the object only. However, in (la) and in the following example the different readings of the subjects are available under the same intonation:

$$
\begin{aligned}
& \text { da ja doch junge Frauen diese SENDung angeschaut haben } \\
& \text { since PRT young women this broadcast watched have }
\end{aligned}
$$

This shows that it is not the intonation itself which differentiates the generic and the existential reading of indefinites. That in (4) the two readings of the sentences are associated with different intonations is because a generic phrase can not be a focus exponent but an existential one can. ${ }^{1}$ Thus, if an object in (4) is generically interpreted it can not be the constituent with primary accent.

Note that $(4 b, c)$ show that a generic bare plural may stay inside the VP independently of Diesing's assumption about the position of modal particles. The subject of (4b) is an indefinite wh-pronoun. Such an element cannot be scrambled (e.g. Haider 1993). Since the subject stays in its base position, the following object certainly is inside the VP. The preferred reading of the subject in $(4 \mathrm{c})$ is the existential reading. Thus, according to Diesing, it is situated inside the VP. It follows that the object must be in the VP as well although it can be interpreted generically. ${ }^{2}$

Other strong readings are also possible for an indefinite which is situated in the VP:
a. Hans möchte heute wem einen Artikel zeigen (und zwar seinen ersten in H. wants today s.o. an article show (namely his first in Phonologie) (specific) phonology)
b. weil wer zwei Linguisten in seinem Haus beherbergt (partitive) because s.o. two linguists in his house accommodates

In (6a) the speaker has a certain article written by Hans in mind. (6b) may talk about two linguists who belong to a given set.

The data considered so far show that $(2 b)$ has to be rejected. Instead the following holds in German:

An indefinite NP in its base position can get a strong reading.

The same is true for Dutch, another scrambling language, cf. de Hoop (1992).

1 Neither can a universally quantified NP be a focus exponent (cf. (ia)); however, a definite NP can play this role (ef. (ib) or (5)):

(i) a. Heute hat Otto jedes HEMD gebuigelt Today has $\mathrm{O}$. every shirt ironed

b. Heute hat Otto sein blaues HEMD gebügelt (wide focus possible) Today has $O$. his blue shirt ironed

2 These data are also problematic for approaches like Tsai (2001), where the strong reading of an indefinite is always the result of interpreting a copy in a movement chain of the indefinite which is outside the domain of existential closure. 


\section{The domain of the weak reading}

The possibility of a weak reading of an indefinite in the middle field is restricted:

$$
\begin{aligned}
& \text { *weil die Polizei Linguisten gestern verhaftet hat (weak reading) } \\
& \text { because the police linguists yesterday arrested has }
\end{aligned}
$$

The indefinite in (8) is situated in front of a temporal adverbial. In this position it cannot get an existential interpretation.

However, there are adverbials in front of which an indefinite can get a weak reading:

weil die Polizei Linguisten im Stadtpark verhaftet hat because the police linguists in the municipal park arrested has

In (9) the indefinite precedes a locative adverbial. An indefinite preceding e.g. a manner adverbial or an instrumental can also get the existential reading:

(10) a. Heute hat Otto Kolleginnen zärtlich umarmt

Today has $O$. colleagues tenderly embraced

b. Heute hat Otto Passanten mit seinem Gesang erschreckt

Today has $O$. pedestrians with his singing frightened

Analyzing different data from those considered here, Frey \& Pittner (1998) argue that the different adverbial types have different base positions in the middle field. For example, it is argued that the base position of a manner adverbial is next to the base position of the verb (or verbal complex) and that locative and instrumental adverbials belong to the class of adverbials whose base positions are right below the base position of the highest argument of the verb. In contrast, temporal adverbials belong to that class of adverbials whose base positions are right above the highest argument. ${ }^{3}$ This is the highest position occupied by adverbials which relate to the eventuality denoted by the clause. Thus, the difference between (8) on the one hand and (9) as well as (10) on the other should be related to the fact that in (8) the indefinite is higher than the base position of the temporal (and, ergo, of the base of the subject) whereas in (9) and (10) it is below the base of the subject. This leads to the following characterization of the domain for the weak reading of indefinites (cf. also Haider \& Rosengren 1998, Frey \& Pittner 1998):

(11) An indefinite that depends on a verb and occurs in the middle field of a German clause can be existentially interpreted only if it is situated inside the minimal maximal projection which contains all the base positions of the dependants of the verb and all the licensers of the indefinite.

This category will be called the minimal domain of the associates of the indefinite (MDA).

3 Adverbials of the same class are not ordered with respect to each other. See Frey \& Pittner (1998) on how other adverbial types fit into these distinctions. 
An element depends on a verb if it is an argument of the verb or if it belongs to the adverbial types that specify the eventuality argument of the verb (e.g. temporals, locatives, instrumentals, manner adverbials). ${ }^{4}$

We may assume that in German, for every indefinite dependent on the verb the syntactic category corresponding to its MDA is the VP (or $v \mathrm{P}) .{ }^{5,6}$ However, it is obvious that the MDA does not correspond to Diesing's concept of the VP and that (11) does not give the same results as Diesing's condition (2a). These are the differences:

(i) As (9) and (10) show, certain adverbial types have their base position inside the MDA.

(ii) Scrambling is possible inside the MDA.

(iii) According to (7), strong indefinites may occur in the MDA.

The following examples, in which the MDA $(=V P)$ is marked by parentheses, illustrate these properties:

(12) a. weil [ein Kollege Pressemitteilungen $n_{1}$ einer Kollegin $t_{1}$ vorliest] because a colleague press statements.ACC a colleague.DAT reads 'because a colleague reads press statements to a colleague' (Acc-obj. can be existential or generic)

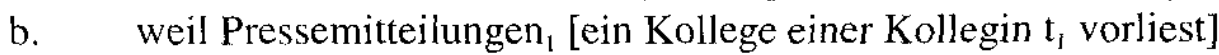
(Acc-Obj. only generic)

c. weil [in einigen Jahren Orkane im Mittelmeer entstehen] because in some years hurricanes in the Mediterranean Sea arise (Subj. existential or generic)

d. weil Orkane, [in einigen Jahren $t_{1}$ im Mittelmeer entstehen] (Subj. only generic)

e. weil [früher in Hinterhöfen, die Jungen $t_{1}$ Fußball spielten] because in former times in backyards the boys soccer played (Locative existential or generic)

f. weil in Hinterhöfen, [frïher die Jungen $t_{1}$ Fußball spielten] (Locative only generic)

g. weil in Hinterhöfen, [die Jungen $t_{1}$ Fußball spielten] (Locative only generic)

\footnotetext{
4 Arguments are meant to be subcategorized phrases which refer to objects in contrast to predicative phrases.

We assume that if a PP is dependent on a verb, so is the complement of the head P.

5 For the simplicity of the discussion we assume that the adverbial types mentioned here are adjoined to the verbal projection.

6 In English an indefinite subject in Spec,IP can get a strong and a weak interpretation. Because in English the subject gets its case in Spec,IP the MDA of the subject corresponds to IP in English. In German, case is licensed in the theta-positions and the MDA always corresponds to VP. The same is true for Dutch. A subject in Spec,IP has a strong reading only (cf. de Hoop 1992). This is expected because in Dutch a subject can get case in its base position, i.e. like in German it does not have to move to be fully licensed.
} 
In (12a) the accusative is scrambled across the other object but is still inside its MDA. An existential interpretation is possible. In (12b) the same argument has left this domain and thus gets only a generic interpretation. In (12c) the subject is in its base position, and it can get a strong or weak reading. In contrast, the subject in (12d) is in front of a temporal adverbial and thus has left the MDA. It is interpreted generically. In (12e) a locative is scrambled to a position between a temporal adverbial and the subject. A temporal in its base position marks the upper boundary of the MDA but still belongs to it. Therefore the locative in $(12 \mathrm{e})$ is inside its MDA, and it can have a weak reading. In (12f) the locative is scrambled outside its MDA. Thus only the generic reading is left. The same is true for $(12 \mathrm{~g})$. Note the difference in meaning between (12e) and $(12 \mathrm{~g})$. The latter does not contain a temporal, therefore the MDA is 'closed' right above the subject.

Before we end this section, a remark is necessary. The preceding observations hold for indefinites under normal intonation. If they are assigned a heavy pitch as in the following examples, they behave differently:
a. weil PulLOver, Maria $\mathrm{t}_{1}$ verschenkt hat (aber keine HEMden) because pullover $M$. given away has (but no shirts)
b. Hans hat FIsche, gestern $\mathrm{t}_{1}$ gefangen (keine KRABben) H. has fish yesterday caught (no prawns)

In (13) the indefinites are contrastively focused. They can get an existential interpretation although they are moved out of their MDAs. These are examples of so called focus scrambling, which is discussed in Neeleman (1994). Focus scrambling is an instance of $\mathrm{A}^{\prime}$-movement and differs from the standard reordering in the middle field. For example, focus scrambling (in contrast to regular scrambling) necessarily undergoes reconstruction for the purpose of semantic interpretation. The readings of the sentences in (13) are therefore expected. Other examples of focus scrambling are given in (14):

a. weil GRÜN, $/ *$ grün, Otto die Wand $t_{1}$ streichen möchte because green $O$. the wall paint wants

b. weil ALle Filme /alle FILme $_{1}$ mindestens einer $t_{1}$ gesehen hat because all films at least one seen has (only: $\quad \exists \forall$ )

(14a) shows that, for example, a resultative can be focus scrambled but the same phrase cannot undergo standard scrambling. The sentence (14b) has only the reading that would arise if the moved phrase were in its base position. This confirms that the moved element is obligatorily reconstructed.

\section{On some claims about scrambling}

De Hoop (1992) states that:

(15) Weak indefinites cannot be scrambled. 
Her conclusion is based on Dutch examples like (16), the German equivalent was given in $(8)$.

(16) *dat de politie taalkungigen gisteren opgepakt heeft that the police linguists yesterday arrested has

Other authors (e.g. Lenerz 1977, 2001, Choi 1999) also assume (15). However, in section 2 it was argued that scrambling of a weak indefinite is possible inside its MDA. If we replace the temporal adverbial in (8), which is an element at the boundary of the MDA, by a locative, which is inside the MDA, the sentence becomes fine as was shown in (9), repeated here for convenience:

$$
\text { weil [die Polizei Linguisten, im Stadtpark } t_{1} \text { verhaftet hat] }
$$

Therefore we may conclude that de Hoop (1992) arrived at (15) by considering only a subset of the different adverbial types. The underlying assumption was that the different adverbial types all have their base outside the VP. However, our findings show that this assumption is highly dubious.

That a weak indefinite may scramble as long as the target position is inside its MDA was also shown by the indefinite object in (12a). The reason that de Hoop did not consider sentences like (12a) could be that scrambling of an object across another one is just not an option in Dutch. ${ }^{7}$

The effects of scrambling are not well understood and there is much disagreement among the syntacticians working on this subject. Specifically, it is not known what the effect of scrambling as in (9) or (12a, e) is. But whatever this effect might be, the examples show that it does not destroy the possibility of an existential interpretation.

Note that examples like (9) and (12a, e) and the fact that strong indefinites may stay in situ (cf. (7)) contradict an often articulated claim about scrambling, according to which it is triggered by a certain property of strong NPs. Diesing (1997) for example suggests that the reason for scrambling is that definites and strongly interpreted indefinites have to escape existential closure. Besides not acknowledging (7) she overlooks the fact that

The criticism against de Hoop (1992) also applies to Choi (1999), but it is not appropriate for Lenerz (1977, 2001). Lenerz considers examples like the following as pieces of evidence for (15):

(i) Wem hast du ein Buch gegeben?

to whom have you a book given

*Ich habe ein Buch dem/einem Studenten gegeben

I have a book the-DAT/a-DAT student given

Note however that an additional factor may be involved which disfavors scrambling of the indefinite in this case. It seems that a constituent which fills the open position indicated by a preceding wh-phrase wants to precede other non-familiar elements in the clause:

(ii) Wem hat Otto was mitgebracht? to whom has $\mathrm{O}$. something brought

a. Otto hat einem Nachbarn Äpfel mitgebracht O. has a-DAT neighbor apples brought

b. ??Otto hat Äpfel, einem Nachbarn $t_{1}$ mitgebracht

(iii) Was hat Otto wem mitgebracht'? What has $O$. to whom brought?

a. ??Otto hat einem Nachbarn Äpfel mitgebracht

b. Otto hat Äpfel $l_{1}$ einem Nachbarn $\mathrm{t}_{1}$ mitgebracht

Note that the weak object in (iiib) is scrambled. 
scrambling can occur inside VP. For Delfitto \& Corver (1997) the trigger for scrambling is the feature [+familiar], which has to be checked in the syntactic structure. All strongly interpreted indefinites but no weak ones are supposed to carry this feature. Again, it is not accounted for that a weak indefinite can, and a strong indefinite does not have to scramble.

A view on scrambling that is inspired by phonological considerations is offered by Neeleman \& Reinhart (1998). According to that view, scrambling is triggered by the need to destress a constituent. A constituent is destressed if and only if it is discoursegiven (D-linked). In a scrambling language scrambling is preferred to get the result of destressing a constituent. Therefore, according to Neeleman \& Reinhart, a discoursegiven constituent is scrambled in order not to be the target of the nuclear stress rule.

However, this cannot be the whole story about scrambling. First, as we have seen, a weak indefinite may scramble, and such an element is not discourse-given. Second, it is possible to scramble the indirect object of a ditransitive verb:

$$
\begin{aligned}
& \text { weil heute Fussballspielern }{ }_{1} \text { Linguistinnen } t_{1} \text { Blumen schickten } \\
& \text { since today soccer players.DAT female-linguists flowers.ACC sent }
\end{aligned}
$$

The indirect object in (17) can be interpreted generically or existentially. Note that in its base position the indirect object could have the same interpretations and would not be the target of the nuclear stress rule, so destressing cannot be the reason for scrambling in this case. Third, Neeleman \& Reinhart consider generic indefinites as somehow Dlinked. However, as predicted by (7), the indefinite in the following sentence can have a generic interpretation:

weil die Polizei gestern Linguisten verhaftet hat

because the police yesterday linguists arrested has

In (18) there is the option for the generic indefinite to scramble. Given the assumptions of Reinhart \& Neeleman, we would expect that it must scramble. This, however, is not true.

Büring (2001) subscribes to (15). In order to explain the deviance of Lenerz' example which was given above in Fn. 7 under (i), he formulates a prosody-based constraint. According to this constraint the nuclear scope consists of complete accent domains all of which contain focus. The nuclear scope can start at any focal accent domain and then continues until the end of the clause. According to Büring, Lenerz' example is bad because there is no position to insert the boundary of existential closure: Inserting it in front of the accusative would violate the constraint that the nuclear scope only contains phrases with focus, inserting it after the accusative would leave this element without existential force.

Büring's constraint is not compatible with our findings. Although for Büring the boundary for existential closure is not given by a certain syntactic category but is influenced by prosody and information structure, Büring's approach, like Diesing's, assumes that existential closure starts at a certain boundary in the clause and keeps its force till the end of the clause. Therefore a sentence like (4c) should not have a reading with an existential subject and a generic object. The object follows a weakly interpreted subject and should be affected by existential closure. But the sentence does have the reading in question. 


\section{Indefinites as members of a complex predicate}

In this section we will look at a domain which is reserved for the weak reading. No strong reading is possible here. This is illustrated by the following examples:

(19) a. Der Kanzler hat neulich Akten grüdlich studiert the chancellor has recently documents thoroughly studied (indefinite can be weak or strong)

b. Der Kanzler hat neulich gründlich Akten studiert (indefinite only weak)

The indefinite in (19a) can get a weak or a strong reading. The indefinite follows a temporal adverbial and precedes a manner adverbial. It is inside its MDA. However, if we let the indefinite follow the manner adverbial as in (19b) only the weak reading is available.

In Frey \& Pittner (1998) it is argued that manner adverbials have their base position next to the verb or to the complex predicate ${ }^{8}$. This is motivated by data like the following:

(20) a. ??Der Kanzler hat heute gründlich diese Akten studiert the chancellor has today thoroughly these documents studied

b. *Der Kanzler hat heute gründlich jede Akte studiert the chancellor has today thoroughly every document studied

On the other side there are elements which can appear between a manner adverbial and the verb. Besides an indefinite like in (19b), this is, for example, true for resultatives:

(21) Karl hat die Vase behutsam sauber gewischt

$\mathrm{K}$. has the vase carefully clean wiped

In the literature it is often argued that resultatives form a complex predicate with the verb (e.g. Neeleman 1994, Winkler 1997). Therefore, one should investigate whether an indefinite such as in (19b) can also participate in the formation of complex predicates. If in German an auxiliary combines with a modal, the standard order of the verbal elements does not sound very good. Instead the inversion of the modal is preferred:

(22) a. (?)dass Hans heute dieses/jedes Hemd bügeln müssen wird that $\mathrm{H}$. today this /every shirt iron must will

b. dass Hans heute dieses/jedes Hemd wird bügeln müssen

c. *dass Hans heute wird dieses Hemd bügeln müssen

d. *dass Hans heute wird jedes Hemd bügeln müssen

(22a) shows the standard order of verbal elements and (22b) the inversion. (22c, d) illustrate that an argument cannot be carried along in such an inversion structure. This suggests that only elements of the complex predicate can participate in the inversion.

8 If a German clause contains auxiliaries or modals a complex predicate is formed, cf. e.g. Haider (1993). 
Interestingly, indefinites can be part of the inversion (cf. (23a)). The same is true for resultatives (cf. (23b)):

(23) a. dass Hans heute wird Hemden bügeln müssen

b. dass Hans heute die Vase wird sauber wischen müssen

Under the assumption that inversion only affects elements of the complex predicate, (23a) shows that indefinites can belong to a complex predicate.

Unlike a resultative, a depictive cannot be part of a complex predicate (cf. Neeleman 1994, Winkler 1997). This explains the following contrast:
a. *Maria hat heute gründlich Patienten betrunken untersucht
M. has today thoroughly patients drunk examined
b. Maria hat heute spielerisch Patienten unter den Tisch getrunken
M. has today playfully patients under the table drunk

All the elements following a manner adverbial have to be part of a complex predicate. The indefinite and the resultative in (24b) both fulfill this requirement. However the depictive in (24a) cannot belong to the complex predicate and therefore causes ungrammaticality.

Neeleman (1994) argues convincingly that a stranded preposition incorporates into a complex predicate in Dutch. In German, preposition stranding only occurs in the split construction with $d a$ - It seems that in this case, too, the preposition is part of a complex predicate:
a. Da hat Otto sorgfältig mit gearbeitet
There has O. carefully with worked
'O. has carefully worked with this'
b. *Da hat Otto mit sorgfältig gearbeitet

The stranded preposition is ungrammatical before a manner adverbial $((25 b))$. Under the assumption that stranded prepositions are part of a complex predicate the following data confirm that the same can be true for indefinites in contrast to arguments:

(26) a. da hat er mit Hunde vertrieben

there has he with dogs chased-away

'he has chased away dogs with it'

b. * da hat er mit diesen/jeden Hund vertrieben

there has he with this/every dog chased-away

'he has chased this/every dog away'

Finally note that an indefinite but not a full argument can be part of a nominalization with a verbal base:

(27) a. das Hemdenbügeln

the shirts-ironing

b. *das jedes-Hemd-Bügeln

the every-shirt-ironing 
According to the DRT view, an indefinite enters the syntactic structure as a predicate. The binding of its variable is done by other elements of the structure. In the special cases considered in this section the indefinite is part of a complex predicate. It is reasonable to assume that in this case the existential binding is induced by the verb itself. We may think of this as a mechanism similar to the one which allows to omit an argument as in:
Otto isst gerade
O. eats at-the-moment
' $O$. is eating'

As is well known, in such examples the omitted arguments are interpreted existentially. The following rule seems to be reasonable:

Indefinites which are part of a complex predicate are bound by existential closure induced by another element of the complex predicate. ${ }^{9}$

In most cases it makes no significant difference whether the existential binding of an indefinite is induced by the predicate in the course of complex predicate formation as in (30a) or whether it happens inside the MDA as in (30b). Therefore the sentences in (30) seem to be synonymous:

(30) a. weil Otto heute sorgfältig ein Hemd/Hemden gebügelt hat that $O$. today carefully a shirt / shirts ironed has

b. weil Otto heute ein Hemd/Hemden sorgfältig gebügelt hat

However, there are verbs where there is such a difference. This is illustrated by the following examples (from Eckardt, to appear):
a. dass Hans geschickt eine Flöte schnitzte
that $\mathrm{H}$. skillfully a flute carved
b. *dass Hans eine Flöte geschickt schnitzte

The verb in (31) is a verb of creation. Such a verb denotes an event which describes the creation of a new object rather than a treatment of a given one. As $(31 \mathrm{a}, \mathrm{b})$ show, with such verbs an existential indefinite can only occur after a manner adverbial, i.e. in our view it has to be part of the complex predicate formation. The binding of the indefinite has to be induced by the verb.

9 This statement is not quite correct. In an example like the following, which describes a habitual property, the object has to follow a manner adverbial and therefore is part of a complex predicate according to our considerations:

(i) a. dass Otto sorgfältig Briefmarken sammelt

that $O$. carefully stamps collects

b. *dass Otto Briefmarken sorgfältig sammelt

As Hans Kamp (p.c.) has pointed out, the object in (ia) has neither an existential nor a generic reading.

Examples like (ia) are very complicated from a semantic point of view, and I am not in a position to discuss them here. Intuitively, it certainly makes sense that their objects should be part of a complex predicate. 
This observation makes sense. A verb of creation expresses that after the event of creation is completed, the appropriate object will exist. However a sentence like (31a) can be true although the event of creation is not completed and consequently the object does not exist in the model. This shows that the existence of the object does not have to become part of the described event but is just part of the intentions or plans which are denoted by the verb. The syntactic correspondence of this fact is that the indefinite has to belong to the complex predicate like in (31a).

In contrast, the existential requirement which is expressed by a weakly interpreted indefinite bound in the MDA has to be fulfilled by the described event, i.e. from a sentence like (30b) it follows that there exist(s) a shirt/shirts. ${ }^{10}$ Now, in (31b) the indefinite has to be bound in the MDA and the predicate of the sentence is a verb of creation. Thus, the existence of the object follows and it does not follow. This semantic contradiction causes the ungrammaticality of the sentence.

Let us conclude this section with a remark on van Geenhoven (1998). Van Geenhoven assumes that bare plurals denote properties and that every weakly interpreted bare plural in German is incorporated into the verb, i.e. to be part of a complex predicate is supposed to be the general case for weak bare plurals and is not, as we assume, restricted to indefinites occurring below the base position of manner adverbials.

There are problems with this approach. First, as (4c) shows, an existential bare plural can precede a generic one. Because incorporation presupposes adjacency, the generic indefinite also ought to incorporate. However, this is not compatible with van Geenhoven's assumptions. Second, it cannot be explained why the object in (19a) has a weak and a strong reading, whereas the object in (19b) can only be weakly interpreted. Third, van Geenhoven assumes that the type mismatch which is created by the demand of the verb for an object and the fact that bare plurals denote properties is solved by a operation on the predicate, which introduces an existential quantifier over instances of the property. Since this is a lexical operation, it follows that every weak bare plural should have narrow scope with respect to any other operator in the clause. However, as the example (47b) in section 6 below will show, this is not true for an indefinite which gets its existential reading in its MDA.

\section{Strong indefinites and information status}

Some authors assume that strong indefinites are topics, cf. e.g. Jäger (1996), ErteschikShir (1997). Since there are many different notions of topic around, an evaluation of this claim would require a careful discussion of the different concepts. This can not be done here. Rather it will be shown that the claim is not compatible with the findings of Frey (2000) about a topic position in German.

10 Correspondingly, the object of an opaque verb like seek has to follow a manner adverbial if the sentence ought to have the de dicto reading:

(i) a. weil Otto intensiv eine Frau gesucht hat (de dicto possible) because $O$. intensively a woman sought has

b. weil Otto eine Frau intensiv gesucht hat (only de re)

Thus, if the object occurs in front of a manner adverbial the sentence implies its existence. 
In Frey (2000) it is argued that there is a designated position for aboutness topics in the middle field of a German clause. This position is right above the base position of sentence adverbials. Sentential adverbials are those adverbials which express the speaker's evaluation of the proposition expressed by the clause. The base position of sentence adverbials is higher than the base position of any other element of the clause (cf. Frey \& Pittner 1998). Two of the various phenomena which support the thesis of a designated topic position are the following:

(32) Da wir gerade von Hans sprechen.

Since we right now of $H$. speak 'Speaking about Hans'

a. Nächstes Jahr wird den Hans erfreulicherweise eine vornehme Dame

Next year will the-Acc $\mathrm{H}$. fortunately a fine lady heiraten

marry

b. \#Nächstes Jahr wird erfreulicherweise den Hans eine vornehme Dame heiraten

(33) a. Sein, Vater wird dem Otto ${ }_{1}$ wahrscheinlich das Auto ausleihen

His father will the-DAT O. probably the car lend

'Probably, Otto's father will lend him the car'

b. *Sein, Vater wird wahrscheinlich dem Otto, das Auto ausleihen

The context in (32) forces Hans to be an aboutness topic in the following sentence. $(32 \mathrm{a}, \mathrm{b})$ show that under such circumstances the item in question has to precede a sentence adverbial. The examples in (33) contain cataphoric pronouns. According to Kuno (1972) and Reinhart (1995) cataphoric pronouns can corefer only with topics. Under this assumption, (33a, b) also show that there is a designated topic position in front of the sentential adverbials in the middle field.

In section 1 it was shown that indefinites in their base position can have a strong reading. Obviously, these strongly interpreted indefinites can not be topics according to Frey (2000). But even indefinites which are positioned higher than the MDA and therefore only have the strong reading are not necessarily topics. This can be shown as follows: As mentioned above, the base position of sentence adverbials is higher than the base positions of any other elements. So we can scramble an indefinite to a position between the base position of a sentential adverbial and, say, the base position of a temporal adverbial:

(34) weil erfreulicherweise Väter an Weihnachten mit der Eisenbahn spielen since fortunately fathers at Christmas with the model railway play

The indefinite in (34) can only be strongly interpreted. Given (11) this is expected because the indefinite is higher than a temporal adverbial and therefore must be outside the MDA. However, according to Frey (2000) this indefinite cannot be a topic because it is still below the sentential adverbial. The following data confirm this:

(35) Da wir gerade von Vätern sprechen.

'Speaking about fathers'

a. Ich habe gehört, dass Väter erfreulicherweise an Weihnachten mit der I have heard that fathers fortunately at Christmas with the 

Eisenbahn spielen
model railway play
b. \#Ich habe gehört, dass erfreulicherweise Väter an Weihnachten mit der Eisenbahn spielen

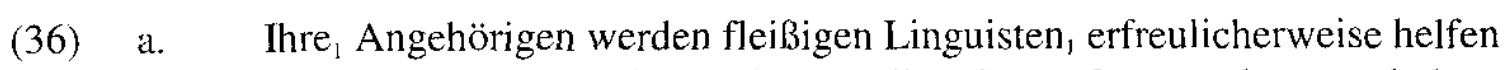
Their relatives will diligent linguists fortunately help

b. $\quad *$ Ihre $_{1}$ Angehörigen werden erfreulicherweise fleißigen Linguisten, helfen

Thus we arrive at the following claim:

(37) The strong reading of an indefinite is not a sufficient condition for its status as a topic.

Let us now consider sentences with a so called individual level (IL-) predicate:

(38) weil Linguistinnen klug sind

The applicability of an IL-predicate to its argument is not restricted to certain times and places. As is well known, the subject of an IL-predicate can only have a strong reading. Thus in (38) the bare plural has only the generic reading.

Let us have a look at the standard account of the fact that the subject of an $\mathrm{L}$ predicate is strongly interpreted. It goes as follows (e.g. Jäger 1996, Erteschik-Shir 1997, de Swart 2001): Every sentence needs to have a topic. In sentences with a stage level predicate this role can be played by the event argument because stage level predicates talk about a specific situation located in time and space or a generic type of situation. This is not possible in the case of $\mathrm{L}$-predicates because they describe properties which are not tied to particular situations. Therefore the subject argument has to be the topic. Topics must be strong NPs because only these encode a notion of 'aboutness' or 'familiarity'.

This chain of reasoning is in conflict with the thesis of a designated topic position in the German middle field. It can easily be shown that, although the subject of an ILpredicate is interpreted strongly, it does not have to be in this position:

a. weil offensichtlich Linguistinnen intelligent sind (generic) because obviously female-linguists intelligent are

b. weil erfreulicherweise ein Student Fußball liebt (specific) because fortunately a student soccer loves

Thus (37) also holds for sentences with IL-predicates. (39a, b) together with the findings of Frey (2000) show that the fact that individual level predicates necessarily have strong subjects cannot be deduced from the assumption that every clause has to have a topic.

In the next section we will try to give an account of the strong reading of the subjects of IL-predicates which differs from the standard one. 


\section{A cartography for indefinites}

The findings of the preceding sections have revealed the following domains at $S$ structure for the interpretation of indefinites in the middle field of a German clause:

(40) The relation between position and meaning of indefinites in German:

a. The domain of complex predicate formation (below the base position of manner adverbials): An indefinite can only be weakly interpreted.

b. The minimal domain of the associates of an indefinite which is dependent on a verb (MDA) (the minimal maximal projection which contains the base positions of the verb's dependants and all licensers of the indefinite): The indefinite can be interpreted weakly or strongly.

c. The domain above of MDA: The indefinite is necessarily strong.

(40a) was already motivated in section 4 . Let us now make some speculations on how the conditions in $(40 \mathrm{~b}, \mathrm{c})$ could be justified for bare plurals.

Chierchia (1998) investigates the relation between the different meanings of bare plurals in different languages. He argues that in languages like English or German bare plurals can either denote kinds or properties. Thus, if in these languages a bare plural occurs in canonical argumental position, it unambiguously denotes a kind. However, bare arguments also occur with non-kind-selecting predicates. Chierchia assumes that in this case the type of the predicate is adjusted by introducing a quantification over instances of the kind. Chierchia argues that in episodic contexts this yields the existential quantification. He shows that this process is even operative with DPs like the one in the following sentence:
a. That kind of animal is ruining my garden
b. $\quad \exists x[u$ that kind of $\operatorname{animal}(x) \wedge$ ruin $m y \operatorname{garden}(x)]$

The sentence (41a) has the interpretation (41b). The type shifting operation ${ }^{\cup}$ maps a kind to the (plural) property of being an instance of the kind. Chierchia calls the general mechanism which is operative here 'Derived Kind Predication' (DPK):

(42) DPK: $P(k)=\exists x[\cup(x) \wedge P(x)] \quad$ for $P$ a predicate which applies to objects which are non-kinds and $k$ a kind.

Thus Chierchia assumes that in the context of an event specification it is possible to deduce the existence of an instance of the kind for which the predicate of the sentence holds. The same mechanism is extended to bare plurals:

$$
\begin{aligned}
& \text { a. Lions are ruining my garden } \\
& \text { b. ruining my garden (Tlions) } \\
& \leftrightarrow(\text { via DKP) } \exists x[\text { [ lions }(x) \wedge \text { ruin my garden }(x)]
\end{aligned}
$$

We can use Chierchia's proposal in the following way: It is a standard assumption that a verb's theta grid contains an argument position for the eventuality which is denoted by 
the clause ('the E-position'). Among the eventualities at least events and states are differentiated, however there might be more subtypes. Like the other argument positions, the E-position has to be saturated by an element in the syntactic structure. The saturation of the E-position occurs after the other argument places are saturated. Many syntacticians assume an $\mathrm{Asp}(\mathrm{ect}) \mathrm{P}$ (hrase) right above the VP. It is reasonable to assume that the instantiation of the E-position with a specified event is linked to an appropriate AspP. Adopting this assumption we can make the application of DPK dependent on an appropriate AspP and arrive at the following constraint ${ }^{1 \mathrm{t}}$ :

(44) A bare plural dependent on a verb can have a weak reading only if the head of its A-chain is situated in its MDA, and the accompanying AspP of the MDA licenses the specification of an event.

The generic interpretation of a bare plural is derived by Chierchia via a process of accommodation of variables over instances of the kind in the restriction of a generic operator. Let us assume that this process is in principle always available. Thus, if the predicate of a sentence applies to objects which are non-kinds and gets a bare plural as an argument it is possible to derive a universal statement about the instances of the kind. This results in a generic sentence. Thus, we assume that the strong reading of a bare plural is given for free whereas, according to (44), the weak reading of a bare plural is the special case which needs extra syntactic licensing. ${ }^{12}$

That the weak reading of an indefinite is dependent on the specification of a singular event is shown by the following data:
a. I consider firemen available
b. John believes students of this class to be intelligent
c. Max hält Studenten dieses Kurses für intelligent
M. considers students of-this course intelligent

The bare plurals in (45) only have the generic reading. (45a) is of special interest because available is not an individual predicate. However, the adjective by itself cannot specify an event and the matrix predicate does not specify an event in the given example. Therefore no singular event is specified by the sentence. The same is true for the remaining sentences $(45 \mathrm{c}, \mathrm{d})$, no specified event is characterized.

11 To keep the following statement simple, it is assumed that scrambling constitutes an A-chain. However, this assumption is not crucial for our considerations.

12 The other strong readings of indefinites are in principle also available in every argumental position. This is true, e.g., of the specific reading of a singular indefinite (cf. (3b), (6a)).

There are approaches which treat singular indefinites as choice functions. Von Heusinger (to appear) argues that specific indefinites are choice functions which depend on the speaker or a referential expression in the clause. Adopting this view we can relate the fact that the specific interpretation of a singular indefinite is always available to the fact that at least the speaker is always available as a possible anchor for the specific interpretation. If we assume that the weak interpretation of a singular indefinite is represented by a choice function which is dependent on the specification of an event (cf. Lenerz 2001), we can further derive that the weak reading of a singular indefinite is only possible in the restricted environment described in (44). 
Chris Wilder (p.c.) made an important observation with regard to constructions like (45). If such sentences are changed such that the matrix clause specifies a singular event, the bare plurals also change their interpretation:

(46) a. I have considered firemen available

b. John has believed students of this class to be intelligent

c. Max hat Studenten dieses Kurses für intelligent gehalten

d. John has believed that students of this class are intelligent

e. Max hat geglaubt, dass Studenten dieses Kurses intelligent sind

The accusative objects in $(46 a, b, c)$ can be interpreted existentially. Note that their MDAs have accompanying AspPs which now specify episodic frames. ${ }^{13}$ In contrast, in $(46 \mathrm{~d}, \mathrm{e})$ the specification of an event by the matrix predicate does not give rise to the existential interpretation of the bare plurals in the finite complement clauses. The bare plurals in these examples are not in a licensing relation with the matrix predicates. In sum, the data in (45) and (46) constitute nice evidence for the condition in (44).

In the last section we discussed the reading of the subject in sentences like the following:

\section{weil Linguistinnen klug sind}

because female-linguists clever are

According to an often articulated explanation the subject of an $\mathrm{LL}$-predicate has to be a topic and therefore has only the strong reading. We refuted the claim about the obligatory topic status. However, to explain why the subject of an IL-predicate has the strong reading, we do not have to assume that it is necessarily a topic. (44) already explains data like (38) or (39). Because individual level predicates do not specify situations located in time and place, such predicates are not accompanied by an episodic AspP. Therefore according to (44) the weak interpretation of an indefinite subject is not possible.

Let us conclude by a look at the scope of a bare plural. The following sentences are both unambiguous. The scope relation between the quantified NP and the weakly interpreted indefinite corresponds in both sentences to their linear order ${ }^{14}$.

a. $\quad$ Sie hat heute fast jedem Kollegen Zimmer ihrer Villa gezeigt (only: $\forall \exists$ ) She has today almost every colleague rooms of her villa shown

b. $\quad$ Sie hat heute Kollegen fast jedes Zimmer ihrer Villa gezeigt (only: $\exists \forall$ )

Note that this is not expected if the scope of existential closure is the VP. On this assumption both sentences should exhibit the same scope relation between the universally quantified NP and the indefinite. If one assumes that in the German middle field scope relations are fixed at S-structure, then both sentences should have wide scope of the existentially interpreted indefinite. If one believes that in German scope is

13 In (46a) and (46b) the matrix predicate licenses the case of the accusative object and thereforc belongs 10 its MDA, cf. (11). For the German example (46c) it can easily be shown that für intelligent halten constitutes a complex predicate.

14 The same scopal behavior could be shown for generically interpreted indefinites. 
determined at LF and that a universally quantified NP has to leave the VP at LF both sentences should have the reading with wide scope of the universal NP.

In fact the unambiguity of the sentences in (47) shows that in the middle field the scope relation between an indefinite and a quantifier is determined by the c-command relations at $\mathrm{S}$-structure. In this respect, an indefinite behaves like any other scope sensitive element in German. Therefore, the operation which derives the reading of an indefinite cannot be a lexical operation on the predicate (as van Geenhoven 1998 has it) because the syntactic position of a bare plural is crucial for its scope. The semantic mechanism which derives the reading of an indefinite has to apply during the semantic processing of the syntactic structure. However, it has to be applied very locally, i.e. this additional step of semantic processing has to be carried out right after the semantic processing of the lexical material of the indefinite. This operation cannot wait till the interpretation process reaches the VP level.

\section{References}

Büring, D. (2000): What Do Definites Do That Indefinites Definitely Don't? In: Fêry, C. \& W. Sternefeld (eds): Audiatur Vox Sapientiae: a festschrift for Arnim von Stechow. Berlin: Akad. Verlag (studia grammatica 52), 70-100.

Chierchia, G. (1998): Reference to Kinds Across Languages. In: Natural Language Semantics, 6. 339-405.

Choi, H.-W. (1999): Optimizing Structure in Context: Scrambling and Information Structure. Stanford: CSLI Publications.

de Hoop, H. (1992): Case configuration and noun phrase interpretation. Ph.D. thesis, Groningen.

Delfitto, D.; N. Corver (1997): Feature primitives and the syntax of specificity. Ms., Tilburg University.

de Swart, H. (2001): Weak readings of indefinites: type-shifting and closure. In: The Linguistic Review 18. 69-96.

Diesing, M. (1992): Indefinites. Cambridge, Mass.: MIT Press.

Diesing, M. (1997): Yiddish VP Order and the Typology of Object Movement. Natural Language \& Linguistic Theory 15. 369-427.

Eckardt, R. (to appear): Manner Adverbs and Information Structure - Evidence from the adverbial modification of verbs of creation. In: Fabricius-Hansen, C. et al. (eds.): Approaching the Grammar of Adjuncts. Berlin: Mouton de Gruyter.

Erteschik-Shir, N. (1997): The Dynamics of Focus Structure. Cambridge: Cambridge University Press.

Frey, W. \& K. Pittner (1998): Zur Positionierung der Adverbiale im deutschen Mittelfeld. Linguistische Berichte 176. 489-534.

Frey, W. (2000): Über die syntaktische Position der Satztopiks im Deutschen. In: Schwabe, K. et al. (eds.): Issues on Topics. ZAS Papers in Linguistics 20. 137-172.

Haider, H. (1993): Deutsche Syntax - generativ. Tübingen: Narr.

Haider, H. \& I. Rosengren (1998): Scrambling. Sprache und Pragmatik 49. Lund.

Jäger, G. (1996): Topics in Dynamic Semantics. Dissertation, Humboldt-Universität zu Berlin.

Kamp, H. (1981): A Theory of Truth and Semantic Representation. In: Groenendijk, J. et al. (eds.): Formal Methods in the Study of Language. Mathematical Centre, Amsterdam, 277321 .

Kuno, S. (1972): Functional Sentence Perspective: A Case Study from Japanese and English. Linguistic Inquiry 3. 269-336.

Lenerz, J. (1977): Zur Abfolge nominaler Satzglieder im Deutschen. Tübingen: Narr. 
Lenerz, J. (2001): Word order variation: Competition or Co-operation. In: Müller, G. \& W. Sternefeld: Competition in Syntax. Berlin: Mouton de Gruyter, 249-281.

Neeleman, A. (1994): Complex Predicates. Doctoral dissertation, Utrecht University/OTS.

Neeleman, A. \& T. Reinhart (1998): Scrambling and the PF Interface. In: Butt, M. \& W. Geuder (eds.): The Projection of Arguments: Lexical and Compositional Factors. Stanford: CSLI Publications, 309-353.

Reinhart, T. (1995): Interface Strategies. OTS Working Papers. Utrecht University.

Tsai, W.-T.D. (2001): On Object Specificity. In: Jäger, G. et al. (eds): Papers on Predicative Constructions. ZAS Papers in Linguistics 22, 173-190.

van Geenhoven, V. (1998): Semantic Incorporation and Indefinite Descriptions. Stanford: CSLI Publications.

von Heusinger, K. (to appear): Cross-linguistic Implementations of Specificity. In: Jaszczolt, K. \& K. Turner (eds.): Contrastive Semantics and Pragmatics. Oxford: Pergamon.

Winkler, S. (1997): Focus and secondary predication. Berlin: Mouton de Gruyter. 